\title{
The contribution of environmental factors to fish assemblages in the Río Acahuapa, a small drainage in Central America
}

\author{
Francisco S. Álvarez ${ }^{1}$, Wilfredo A. Matamoros ${ }^{2}$ and Francisco A. Chicas ${ }^{3}$
}

The ichthyofauna of the Río Acahuapa was analyzed sampling 17 sites that included the basin main channel and its tributaries. Fish were collected using dip-nets, seine-nets and electrofishing. Fish standard length and species abundance were recorded. Species origin and salinity tolerance criteria were used to classify fish species. Water physicochemical variables, habitat structure and sampling sites elevation were recorded. A total of 33 fish species were registered, $12.1 \%$ are primary, $45.5 \%$ are secondary and $42.4 \%$ are of marine derivation. Fish species richness declined with increase of elevation $\left(R^{2}=0.55, p=0.0006\right)$. Two assemblages of fishes were identified: the first one associated to sites of low elevations (19-184 masl), composed mainly of secondary and marine-estuarine fish species related with high temperature, water velocity, river width, dissolved oxygen and low sand and silt substrate cover; the second one associated to sites of middle and higher elevations (185-519 masl), composed by primary and secondary freshwater fishes related with high $\mathrm{pH}$, logs and rocks substrate cover. In summary, elevation and environmental variables contributed to the composition and distribution of fish in the Río Acahuapa.

Keywords: Community structure, Fish ecology, Freshwater fish, Habitat structure, Tropical streams.

La ictiofauna del Río Acahuapa fue analizada en 17 sitios que incluyen el canal principal de la cuenca y sus tributarios. Los peces fueron recolectados utilizando chinchorros, redes de mano y electropesca. Se registró la longitud estándar y la abundancia por especie. El criterio de origen y tolerancia a la salinidad de las especies fue utilizado para clasificar a los peces. Las variables fisicoquímicas del agua, estructura del hábitat y elevación se registraron en cada sitio. Un total de 33 especies fueron registradas, cuyo $12.1 \%$ son primarias, $45.5 \%$ secundarias y $42.4 \%$ son de derivación marina. La riqueza de especies de peces disminuyó con el aumento de la elevación $\left(\mathrm{R}^{2}=0.55, \mathrm{p}=0.0006\right)$. Dos ensamblajes de peces fueron identificados: el primero está asociado con sitios de bajas elevaciones (19-184 msnm), compuesto principalmente de especies de peces secundarias y marino-estuarinas relacionadas con altas temperaturas, velocidad del agua, ancho de río, oxígeno disuelto y baja cobertura de sustrato de arena y limo; el segundo está asociado con sitios de mediana y alta elevación (185-519 msnm), compuesto por peces dulceacuícolas primarios y secundarios relacionados con altos valores de $\mathrm{pH}$ y cobertura de sustrato de troncos y rocas. Se determina que la elevación y las variables ambientales contribuyen a la composición y distribución de peces en el Río Acahuapa.

Palabras-clave: Arroyos tropicales, Ecología de peces, Estructura comunitária, Estructura del hábitat, Peces de agua dulce.

\section{Introduction}

The topographic and climatic conditions are important determining geomorphological traits of a basin (Winemiller et al., 2008). Factors such as elevation, slope and rain regimes mainly influence the dynamics of currents in river systems and create habitat variability along rivers longitudinal gradient (Bussing, 2002; Winemiller et al., 2008; Esselman, Allan, 2010). Some authors explain that this habitat variability determines zonation patterns of species (Rahel, Hubert, 1991). For example, fishes adapted to high water velocities habitats, will occur in rapids zones of the rivers, while species that cannot tolerate high water velocities habitats, will occur in zones of backwaters or pools (Bussing, López, 1977). Likewise, many of these geomorphological characteristics of the basin are also influencing water physicochemical factors, such as: dissolved oxygen, $\mathrm{pH}$, temperature, salinity, and conductivity, which can have an effect on fish communities (Bussing, López, 1977; Wootton, 1992). Moreover, landscape factors such as the watershed area or land-use activities can be strongly correlated with the composition, structure, and distribution of species (Schlosser, 1991; Esselman, Allan, 2010; Junqueira et al., 2016).

\footnotetext{
${ }^{1}$ Departamento de Investigación, UDP Ciencias Neotropicales, Calle Francisco Campos 166, Colonia Escalón, CP 1101, San Salvador, El Salvador.samuel_biologo@hotmail.com (corresponding author)

${ }^{2}$ Instituto de Ciencias Biológicas, Universidad de Ciencias y Artes de Chiapas, Libramiento Norte Poniente 1150, Colonia Lajas Maciel, CP 29039, Tuxtla Gutiérrez, Chiapas, México. wilmatamoros@yahoo.com

${ }^{3}$ Facultad de Ciencias Naturales y Matemática, Escuela de Biología, Universidad de El Salvador, Final Av. Estudiantes Héroes y Mártires del 30 de julio, Ciudad Universitaria, CP 1101, San Salvador, El Salvador. francisco.chicas@ues.edu.sv
} 
Evidence suggests that composition of species may change in a predictable way due to changes in environmental conditions driven primarily by changes along the river continuum (Vannote et al., 1980; Lyons, Schneider, 1990; Lorion et al., 2011). Others suggest that proximity or connectivity with marine or brackish waters may be strong factors that may explain changes in the composition and distribution of species (Esselman et al., 2006; Mercado-Silva et al., 2012). Consequently, these factors are important to explain the dynamics of the fish species, mainly in rivers that have connectivity with brackish waters or altitudinal gradients. However, there are biotic factors that play an important role within the species communities. For example, factors such as migration, competition, predation and mutualism can affect species composition and changes in abundances in a river (Wootton, 1992; Matthews, 1998). The sum of the combined effect of abiotic and biotic factors, may be the main force determining fish communities structure (Schlosser, 1991; Jackson et al., 2001).

The majority of information about the relationships between freshwater fish communities and biotic and abiotic factors is mainly generated in temperate areas (e.g., Wootton, 1992; Matthews, 1998). For the neotropics, information about fish communities is scarce, even more in the Central American region (Lowe-McConnell, 1987; Winemiller et al., 2008; Junqueira et al., 2016). However, in the last decades, some researchers are aiming to improve the understanding of the freshwater fish communities in the area. As a result, there are taxonomic inventories of freshwater fishes for almost all Central American countries (Greenfield, Thomerson, 1997; Kihn-Pineda et al., 2006; Matamoros et al., 2009; Angulo et al., 2013; McMahan et al., 2013). Nonetheless, it is notable a shortage of ecological studies in most of the Central America countries, but Costa Rica and Panama (e.g., Bussing, López, 1977; Angermeier, Karr, 1983; Wootton, Oemke, 1992; Lorion et al., 2011). Particularly in El Salvador a handful of published studies on freshwater fish have been generated (e.g., Hildebrand, 1925; Álvarez et al., 2013; McMahan et al., 2013), focusing on the distribution of species, while the ecological aspects of freshwater fish communities have been neglected.

For the basin of the Río Acahuapa, there are no publications about ichthyofauna in the area and this study represents the first assessment of the influence of environmental factors on freshwater fish assemblages in El Salvador. Therefore, the main goal of this study was to characterize the composition of species in Río Acahuapa basin. To identify the main environmental factors that affect the composition and distribution of the freshwater fish of the río Acahuapa. Likewise, we evaluated the effect of the elevation with regards to species richness in the basin. It is expected that this information will contribute to the understanding of the factors that locally affect the ichthyofauna and that it can support future studies and management strategies and conservation of biodiversity in the basin of the Río Acahuapa.

\section{Material and Methods}

Study area. The Río Acahuapa is located in the Department of San Vicente in the Pacific slope of El Salvador (Fig.1). The Río Acahuapa belongs to Río Lempa drainage system, the most important and the largest basin of El Salvador. The basin area of the Río Acahuapa is $238.88 \mathrm{~km}^{2}$ and the length of the river is $35.3 \mathrm{~km}$ (Hernández et al., 2010). The basin of the Río Acahuapa has no influence of brackish water, its mouth connects with the Río Lempa $45 \mathrm{~km}$ away from the sea. The weather in the area is tropical and the dry season spans from November to April and the rainy season from May to October (McMahan et al., 2013). Most of the Río Acahuapa watershed area is used for livestock and agriculture, which includes crops such as: coffee, sugarcane, several kinds of fruits, vegetables, beans and corn. Also, the Natural Protected Area of La JoyaSisimico is located within the boundaries of the basin, the most important conservation area of San Vicente Department (Hernández et al., 2010).

Sampling sites. Along the river, 17 sites were sampled; six points were located in the main channel and 11 points in tributaries (Fig.1). Seven sampling sites were located from 19 to $184 \mathrm{~m}$, seven from 185 to $351 \mathrm{~m}$ and three locations from 352 to $519 \mathrm{~m}$ of elevation. All the sites were sampled in each of the five sampling campaigns that were performed in June, August, and November 2011, and February and May 2012 (Tab. 1).

To determine the sampling area, first we estimated the mean width of the river in each sampling point. Then, the mean width of the river was used to determine the length of the river that was going to be sampled following the criteria: a) if the mean river width was $<2 \mathrm{~m}=50 \mathrm{~m}$ length of the river were sampled, b) if river width was between 2-5 $\mathrm{m}=$ $75 \mathrm{~m}$ of the river were sampled, c) if the river width was between $5-10 \mathrm{~m}=100 \mathrm{~m}$ of the river were sampled, $\mathrm{d}$ ) if the river width was between $10-20 \mathrm{~m}=200 \mathrm{~m}$ of the river were sampled, e) if the river width was between $20-30 \mathrm{~m}=300 \mathrm{~m}$ of the river were sampled. Due to the lack of standardized protocols for the collection of fish in freshwater ecosystems in El Salvador, this methodology was used to standardize the sampling length due to the differences in size among rivers, as some authors argue that increasing the length of the transect based on the river width enhances the probability of catching specimens in the transect and favors species richness comparisons (Lyons, 1992; Hughes et al., 2002; Watkins et al., 2016).

Fishing gear and preservation. Electrofishing (one backpack electrofisher SAMUS 725MP operated by one person and accompanied by two people), a seine-net and dip-nets were used to catch the fishes. For sampling, zigzag sweeps were performed along the transect width in the opposite direction of the current. All the rivers and streams were wadable and it was possible to perform electrofishing. However, due to habitat variability, the sampling effort was standardized until a maximum of one hour of electrofishing per site, except for the smaller sites, where a single 
sweep with electrofishing was carried out in the transect (Angermeier, Smogor, 1995).The captured specimens were identified in the field using the identification keys of Miller et al. (2009) and Bussing (2002). The standard length (SL) was measured before they were released. Each species was classified by salinity tolerance criteria and the species origin following Myers (1949a) criteria. For migratory species (sensu lato McDowall, 2008), usually sub divided in anadromous, catadromous and amphidromous (Myers, 1949b; McDowall, 2008; Acolas, Lambert, 2016), we used only the single category: diadromous; considering direct and/or indirect evidence on these species available up to the date (Cruz, 1987; Lyons, 2005; Ribeiro, Villalobos, 2010; Lorion et al., 2011; Smith, Kwak, 2014a, 2014b). Fish from marine derivation, that can be considered marine-stenohaline or marine-eurihaline (Espinosa-Pérez et al., 2011), were grouped in a single category of marine-estuarine species. This classification was made under a bibliographic revision available for each of the species (Castro-Aguirre et al., 1999; Bussing, 2002; Lyons, 2005; Miller et al., 2009; McMahan et al., 2013; Smith, Kwak, 2014b). Some individuals were kept and deposited in the scientific collection of the Instituto de Ciencias del Mar y Limnología of the Universidad de El
Salvador (ICMARES-UES 462-472, 505-538; S1 - Available only as online supplementary file accessed with the online version of the article at http://www.scielo.br/ni).

Environmental variables. In each sampling point three transversal transects were deployed. Within each transect the full set of physicochemical parameters (temperature $\left({ }^{\circ} \mathrm{C}\right)$, conductivity (uS/cm), salinity (ppt), dissolved oxygen $(\mathrm{mg} / \mathrm{l}), \mathrm{pH}$ ), habitat structure (water velocity, depth, river width) and substrate cover (rocks, sand, logs, silt and leaves) were measured in the right-shore, middle and leftshore of the river. The water physicochemical parameters were measured using a YSI Multiparameter probe Model 8510.The width and depth of the river were measured using a measuring tape and the water velocity was recorded with a portable flow meter. The percentages of the substrate coverage were estimated with the use of a quadrat of 100 squares of $4 \mathrm{~cm} \times 4 \mathrm{~cm}$ each. We counted the number of squares per substrate and recorded the average percentage of each substrate. The elevation was obtained in each sampling site using a GPS. All the physicochemical parameters and habitat structure variables were measured at each sampling point in each sampling campaign and the averages of each variable for each transects were determined (Tab. 1).

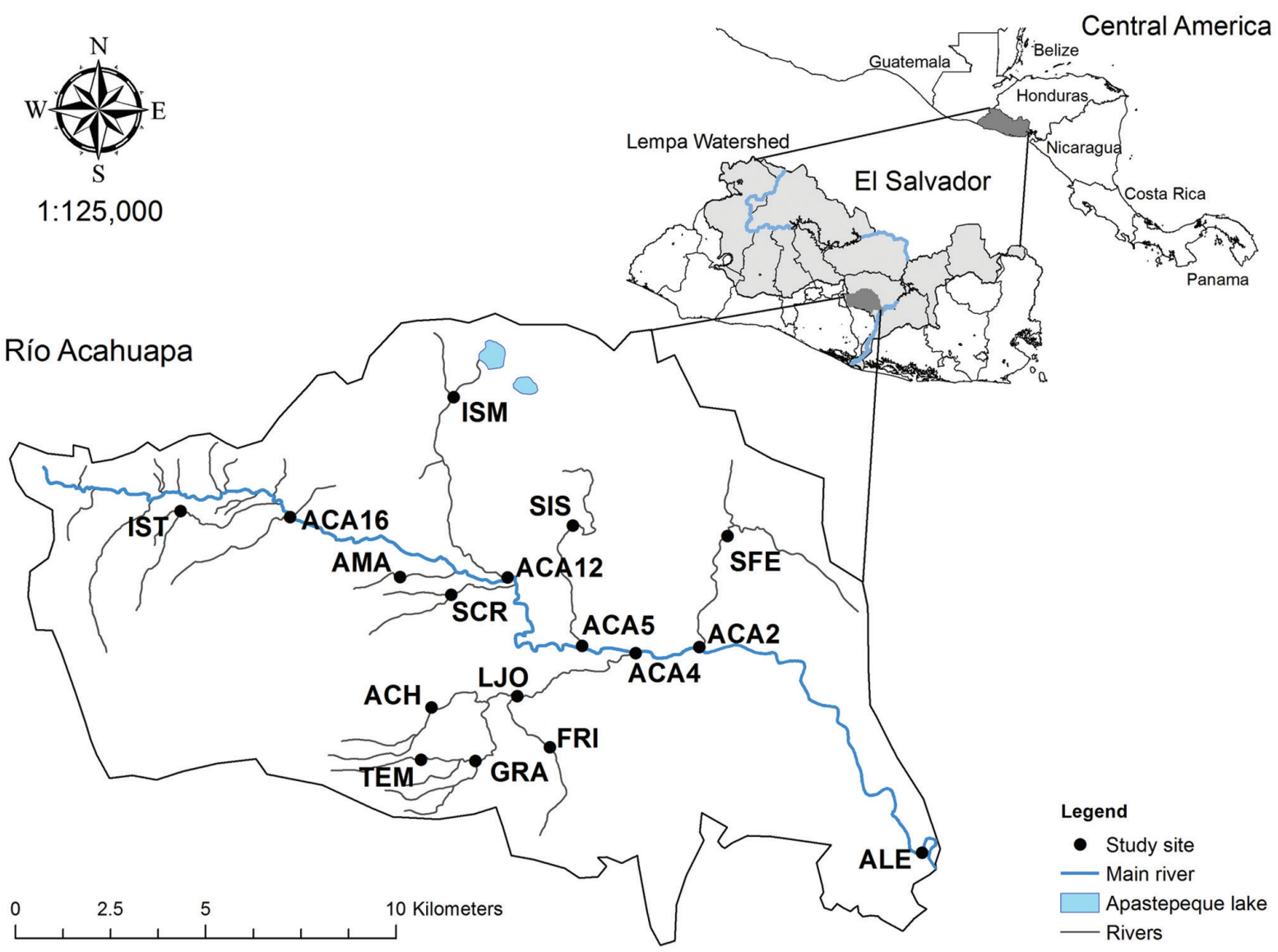

Fig. 1. Sampling sites in the basin of the Río Acahuapa, San Vicente, El Salvador, 2011-2012. Acahuapa-Lempa (ALE), Acahuapa (ACA2), San Felipe (SFE), Acahuapa (ACA4), Acahuapa (ACA5), La Joya (LJO), Frío (FRI), Grande (GRA), Tempates (TEM), Achichilco (ACH), Sisimico (SIS), Acahuapa (ACA12), San Cristóbal (SCR), Amapupulta (AMA), Ismataco (ISM), Acahuapa (ACA16), Istepeque (IST). 
Tab 1. Habitat characteristics of the 17 study sites in the Río Acahuapa, San Vicente, El Salvador, 2011-2012. Average values of each of the environmental variables for five sampling campaigns.

\begin{tabular}{|c|c|c|c|c|c|c|c|c|c|c|c|c|c|c|}
\hline Sites & $\mathrm{T}\left({ }^{\circ} \mathrm{C}\right)$ & $\mathrm{pH}$ & $\begin{array}{c}\mathrm{DO} \\
(\mathrm{mg} / \mathrm{L})\end{array}$ & $\begin{array}{l}\text { Conductivity } \\
\text { (uS) }\end{array}$ & $\begin{array}{l}\text { Width } \\
\text { (m) }\end{array}$ & $\begin{array}{l}\text { Depth } \\
(\mathrm{cm})\end{array}$ & $\begin{array}{l}\text { Salinity } \\
\text { (ppt) }\end{array}$ & $\begin{array}{l}\text { Water velocity } \\
(\mathrm{m} / \mathrm{s})\end{array}$ & $\begin{array}{c}\text { Sand } \\
(\%)\end{array}$ & $\begin{array}{l}\text { Rock } \\
(\%)\end{array}$ & $\begin{array}{c}\text { Leaves } \\
(\%)\end{array}$ & $\begin{array}{l}\text { Logs } \\
(\%)\end{array}$ & $\begin{array}{l}\text { Silt } \\
(\%)\end{array}$ & $\begin{array}{l}\text { Elevation } \\
\text { (m) }\end{array}$ \\
\hline ALE & 30.8 & 6.5 & 9.8 & 325.6 & 23.0 & 23.1 & 0.11 & 0.20 & 61.7 & 28.3 & 2.0 & 1.7 & 6.3 & 19 \\
\hline ACA2 & 31.0 & 6.9 & 6.3 & 331.1 & 19.4 & 28.6 & 0.09 & 0.31 & 18.9 & 41.3 & 3.6 & 33.3 & 2.9 & 95 \\
\hline ACA5 & 30.1 & 7.0 & 6.4 & 364.6 & 15.2 & 24.0 & 0.12 & 0.18 & 25.3 & 33.0 & 2.1 & 31.6 & 8.0 & 110 \\
\hline ACA4 & 31.1 & 6.9 & 6.2 & 258.8 & 11.7 & 25.9 & 0.08 & 0.18 & 25.5 & 28.1 & 3.2 & 30.6 & 12.6 & 115 \\
\hline SFE & 30.0 & 8.5 & 6.6 & 291.6 & 9.6 & 26.4 & 0.05 & 0.18 & 12.9 & 46.1 & 3.7 & 37.4 & 0.0 & 137 \\
\hline SIS & 30.2 & 6.9 & 6.3 & 296.9 & 10.3 & 21.8 & 0.10 & 0.21 & 17.7 & 44.9 & 2.3 & 35.1 & 0.0 & 177 \\
\hline LJO & 30.0 & 6.7 & 6.1 & 226.6 & 11.8 & 27.1 & 0.08 & 0.24 & 46.0 & 29.6 & 1.0 & 21.2 & 2.2 & 184 \\
\hline ACA12 & 26.5 & 6.5 & 4.9 & 224.1 & 5.4 & 11.3 & 0.07 & 0.11 & 27.5 & 32.0 & 2.7 & 21.9 & 15.9 & 267 \\
\hline SCR & 27.4 & 6.7 & 6.4 & 457.7 & 7.3 & 34.3 & 0.08 & 0.21 & 24.6 & 37.1 & 5.5 & 18.9 & 13.9 & 301 \\
\hline AMA & 26.5 & 6.2 & 5.5 & 234.2 & 5.2 & 17.9 & 0.08 & 0.21 & 21.5 & 37.0 & 3.7 & 22.6 & 15.3 & 314 \\
\hline GRA & 27.6 & 6.3 & 5.9 & 225.8 & 4.2 & 24.1 & 0.08 & 0.16 & 24.7 & 38.2 & 2.4 & 18.7 & 16.0 & 325 \\
\hline $\mathrm{ACH}$ & 27.8 & 6.4 & 6.1 & 328.5 & 3.8 & 27.5 & 0.08 & 0.18 & 17.7 & 40.4 & 3.3 & 28.7 & 10.0 & 341 \\
\hline TEM & 27.6 & 6.4 & 5.4 & 484.4 & 4.6 & 13.7 & 0.08 & 0.15 & 13.0 & 39.3 & 2.7 & 33.3 & 11.7 & 348 \\
\hline FRI & 26.1 & 6.2 & 5.4 & 180.3 & 4.3 & 16.9 & 0.08 & 0.12 & 21.9 & 40.5 & 2.5 & 23.2 & 11.9 & 351 \\
\hline ACA16 & 28.3 & 8.0 & 5.5 & 344.4 & 8.3 & 18.0 & 0.08 & 0.17 & 34.3 & 38.5 & 2.0 & 20.2 & 5.0 & 419 \\
\hline ISM & 27.7 & 6.3 & 4.7 & 324.4 & 4.2 & 17.9 & 0.08 & 0.12 & 24.5 & 28.6 & 8.9 & 12.9 & 25.1 & 509 \\
\hline IST & 28.5 & 6.8 & 5.0 & 438.4 & 9.6 & 20.8 & 0.18 & 0.20 & 21.9 & 33.0 & 3.4 & 23.4 & 18.3 & 519 \\
\hline
\end{tabular}

Statistical analysis. To analyze the relationships between environmental variables and sampling sites, a Principal Component Analysis (PCA) was performed. The PCA was carried out using all data of water physicochemical variables (temperature, dissolved oxygen, salinity, $\mathrm{pH}$, and conductivity), habitat structure (water velocity, depth, river width, and substrate types) and elevation (meters above sea level). All the data of the environmental variables were standardized (centering and scaling) to reduce the effect of the measurement units in the PCA analysis.

Subsequently, a Canonical Correspondence Analysis (CCA) was performed to explore the relationship between the fish abundances and the environmental factors (water physicochemical variables, habitat structure and elevation). To describe the environmental factors in the two axes of CCA, we used the PC1 and PC2 scores. In the graphical representation of the CCA, we use the variables that best describe the contribution of the two axes of PCA and a Pearson correlation analysis was performed between the environmental variables and the PC1 and $\mathrm{PC} 2$ values. Only the variables with correlation coefficients $\geq 0.60$ and statistical significance $p>0.05$ were described.

For the CCA, only the data of the most abundant species with presence in two or more sampling points were used, with the purpose of visualizing the contribution of the abundant species in this analysis more clearly. For this study, rare species were considered those species that were captured in a single occasion or in a single location (Cao et al., 2001). Some of the rare species could be the result of natural low abundances influenced by environmental factors or ecological processes that occur in the basin (Magurran, Henderson, 2003).
In order to determine if there were significant differences between fish assemblages detected by the CCA, we applied a one-way analysis of similarity (ANOSIM) (Clarke, 1993). The ANOSIM was implemented using the fish abundances of the identified groups. We used Bray Curtis (Bray, Curtis, 1957) as dissimilarity measure in order to construct our distance matrix, the correction of SidakSS for p-values, 1000 cycles of permutations and non-standardized data. In addition, a linear regression analysis was performed to visualize the effect of elevation on species richness for the Río Acahuapa basin. All the analyses were performed with the statistical package Qeco (Di Rienzo et al., 2010) and InfoStat (Di Rienzo et al., 2011).

\section{Results}

Fish diversity and species composition. A total of 6,742 individuals from eight orders, 14 families, 23 genera and 33 species were captured (Tab. 2). The families with highest species richness were Cichlidae and Poeciliidae with seven and six species respectively, followed by the families Centropomidae and Eleotridae with three species each. Members of the family Poeciliidae represented $77 \%$ of the total abundance, followed by Cichlidae with $6.8 \%$, Characidae with $6.6 \%$, Mugilidae with $3.4 \%$ and Gobiidae with $2.7 \%$, that represented $96.6 \%$ of the total abundance. According to the classification by origin and tolerance to salinity, four species were primary ones representing the $12.1 \%$ of the species richness, followed by 15 species which were secondary and represented the $45.5 \%$ of the species richness, and 14 species of marine derivation represented the $42.4 \%$ of the species richness. Of the latter, three $(9.1 \%)$ are diadromous species and 11 (33.3\%) marine-estuarine. 


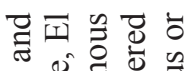

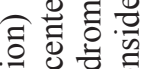

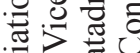

วิ ⿷匚丁

至

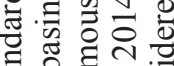

䓪

멸을

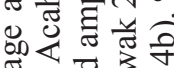

证

웡

에

毛㻤

要

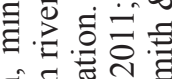

हี 들

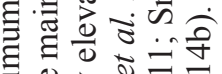

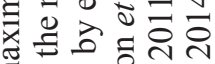

光.

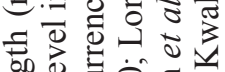

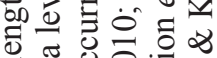

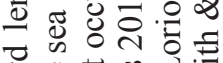

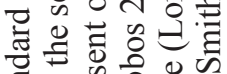

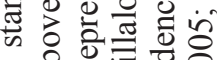

등

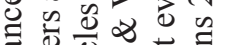

을

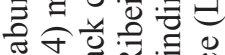

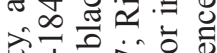

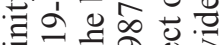

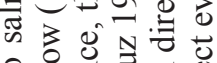

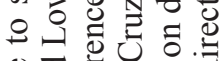

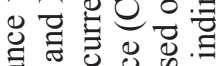

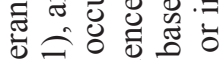

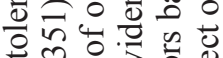

娄它司

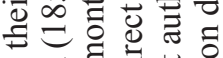

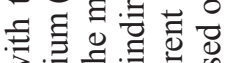

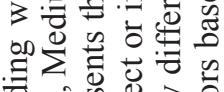

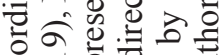

苋产

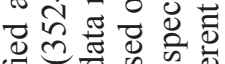

- 0 o
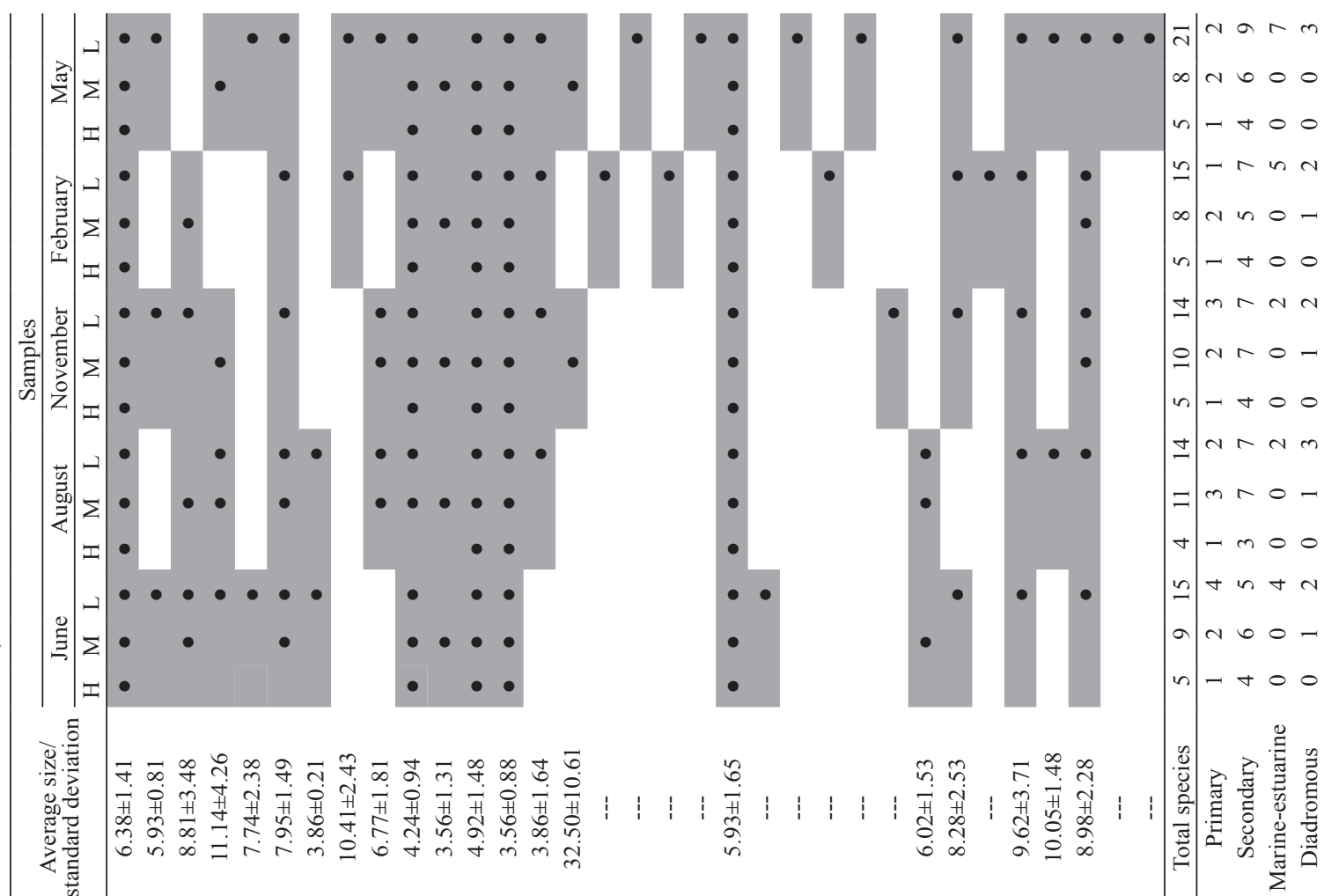

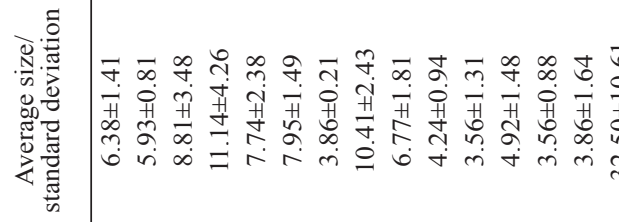

กำ 옴

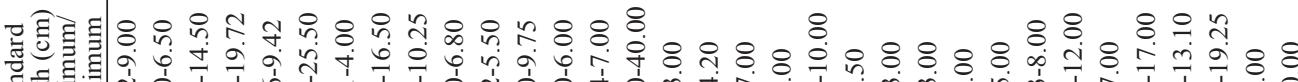

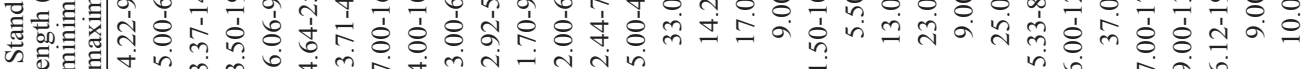

竞

:

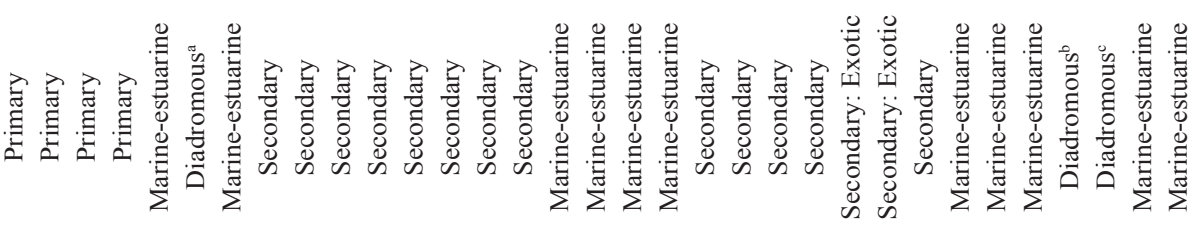

Z

委

说

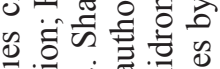

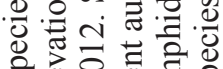

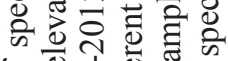

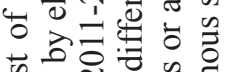

潒

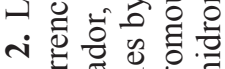

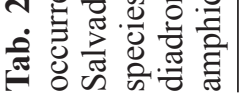

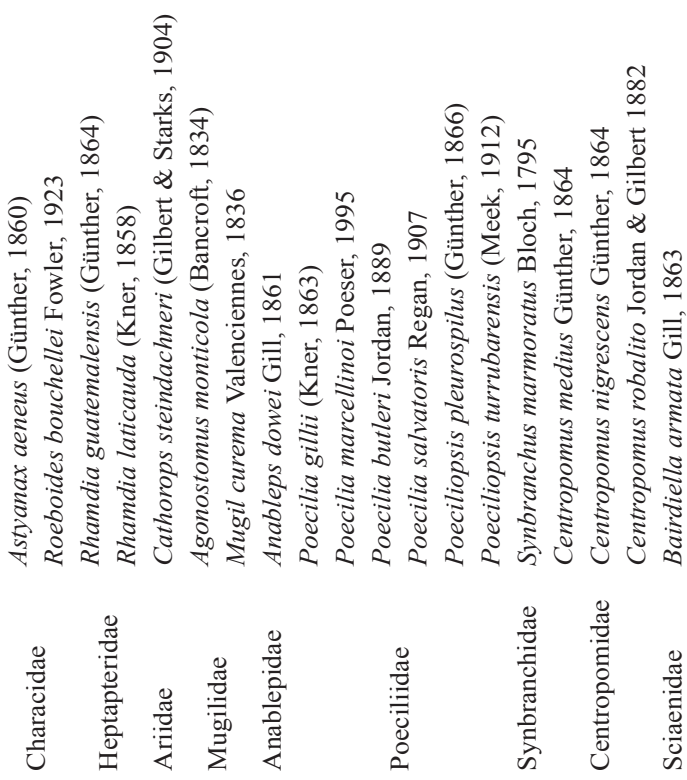

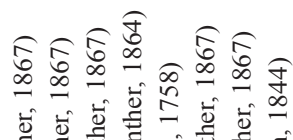

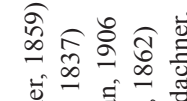

范

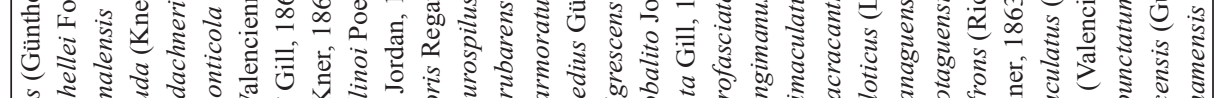

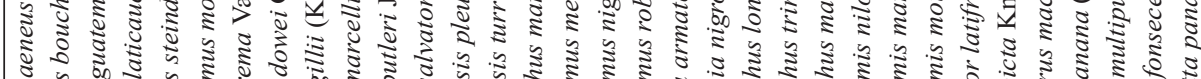

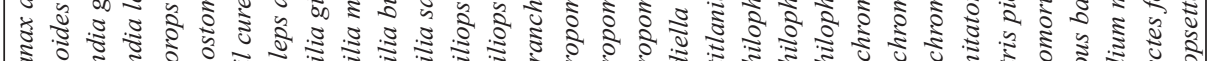

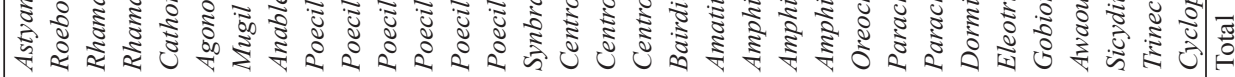

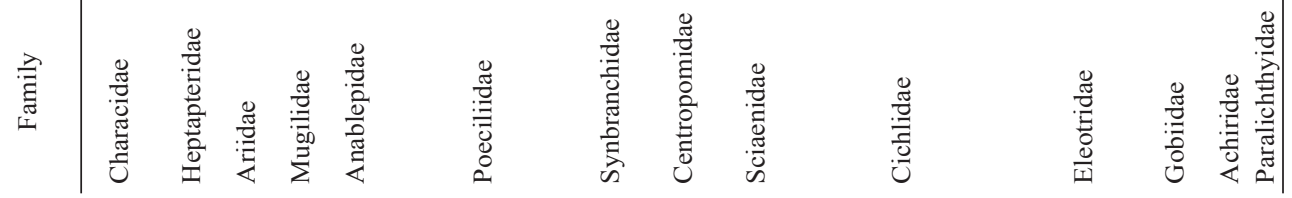


Changes in species richness were related to the elevation (Fig. 2). It indicates that species richness declines with increasing elevation $\left(\mathrm{R}^{2}=0.55, \mathrm{p}=0.0006\right)$. Regarding the species richness registered for the different sampling months, a constant number of primary secondary and diadromous species were observed; whereas an increase in marineestuarine species was observed in February and May between the transition from the dry season to the beginning of the rainy season (Tab. 2). Concerning to species distribution, it was observed that many primary and secondary species are present along the basin, while the diadromous and marineestuarine species are present mainly in sites of low elevation.

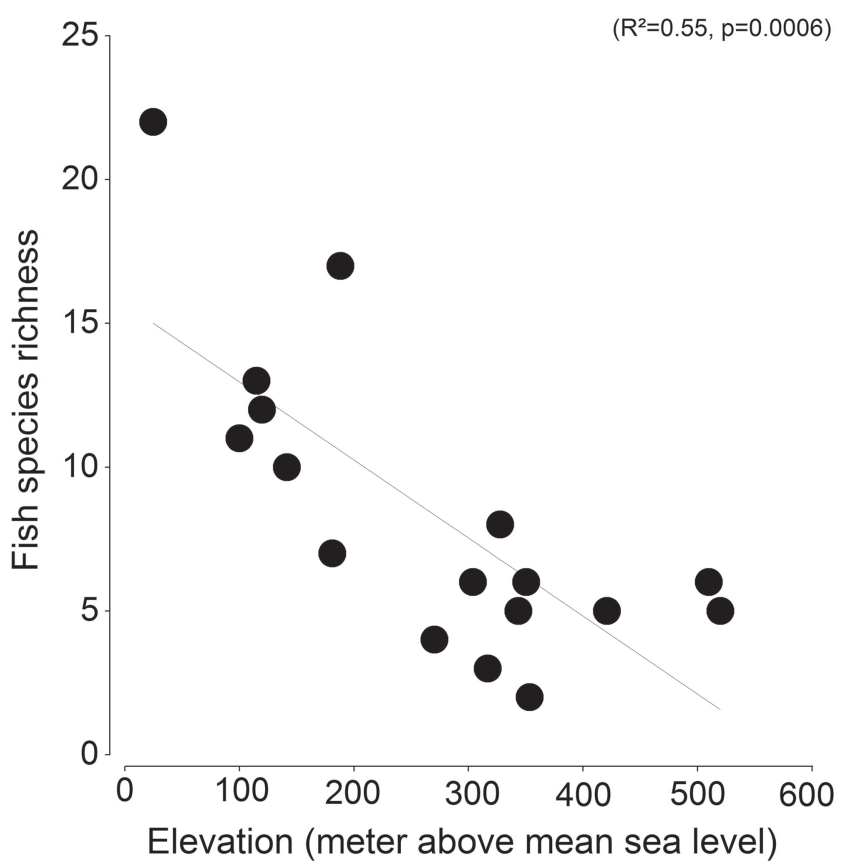

Fig. 2. Relationships between elevation and fish species richness in 17 sampling sites in the Río Acahuapa, San Vicente, El Salvador, 2011-2012.

Relationship between samplings sites, physicochemical factors and variables of habitat structure. The Principal Component Analysis (PCA) of the environmental variables explained a $57 \%$ of the observed variance (Fig. 3). The PC1 contributed with $35 \%$ of the explained variance and it was strongly correlated with water temperature, water velocity, river width, elevation, and dissolved oxygen; whereas, the PC2 contributed with $22 \%$ of the explained variance and it was strongly correlated with the following variables: $\mathrm{pH}$, silt, logs, sand, and rocks (Tab. 3). The PCA showed a relationship among sampling locations, habitat structure, and physicochemical factors in the basin of the Río Acahuapa. Whereas, variables such as water velocity, river depth, river width, dissolved oxygen, $\mathrm{pH}$, salinity and temperature were associated to areas between 19-184 m above the sea level. On the other hand, variables such as leaves, logs, rocks, silt, and conductivity were associated to sites between 185-519 $\mathrm{m}$ above the sea level.
Tab. 3. Results of Principal Components Analysis (PCA), showing the loadings of environmental variables on the first two principal components and the percent of total variance explained by these components. Shaded values in bold represent values with correlation coefficients $>0.60$ and statistical significance $(\mathrm{p}>0.05)$.

\begin{tabular}{lcc}
\hline Variables & PC1 & PC2 \\
\hline $\mathrm{T}\left({ }^{\circ} \mathrm{C}\right)$ & $\mathbf{0 . 3 9 8}$ & 0.092 \\
$\mathrm{pH}$ & 0.153 & $\mathbf{0 . 3 4 6}$ \\
$\mathrm{DO}(\mathrm{mg} / \mathrm{L})$ & $\mathbf{0 . 3 7 5}$ & -0.136 \\
Conductivity (uS) & 0.003 & 0.052 \\
Width (m) & $\mathbf{0 . 4 1 8}$ & -0.090 \\
Depth (cm) & 0.255 & 0.151 \\
Salinity (ppt) & 0.083 & -0.195 \\
Water velocity $(\mathrm{m} / \mathrm{s})$ & $\mathbf{0 . 3 1 0}$ & 0.167 \\
Elevation & $\mathbf{- 0 . 3 7 7}$ & -0.063 \\
Sands $(\%)$ & 0.203 & $\mathbf{- 0 . 4 3 7}$ \\
Rocks (\%) & -0.065 & $\mathbf{0 . 4 7 5}$ \\
Leaves $(\%)$ & -0.205 & 0.042 \\
Logs $(\%)$ & -0.160 & $\mathbf{0 . 4 4 9}$ \\
\hline
\end{tabular}

Relationship between species, physicochemical factors and variables of habitat structure. According to the fish occurrence data, 15 species were identified as rare, consequently 18 species were used for Canonical Correspondence Analysis (CCA). According to the CCA, the first two axes account for $66 \%$ of the variance explained (Fig. 4). The CCA1 contributed with $41 \%$ of the explained variance and showed relationship with the variables of the elevation, temperature, water velocity, width, and dissolved oxygen. While the CCA 2 contributed with a $25 \%$ of the explained variance and showed a relationship with the $\mathrm{pH}$, sand, silt, rocks, and logs.

The CCA showed two groups based on composition and fish abundance in the Río Acahuapa. The first group is associated with locations in the lower areas and the river mouth (19-184 $\mathrm{m}$ above the sea level) and it is composed mainly by secondary fish and marine-estuarine species such as Sicydium multipunctatum (Simu), Agonostomus monticola (Agmo), Poecilia gillii (Pogi), Poeciliopsis pleurospilus (Popl), Anableps dowei (Ando), Dormitator latifrons (Dola), Gobiomorus maculatus (Goma), Awaous banana (Awba) and P. turrubarensis (Potu). While the second group is associated with middle and higher areas (185-519 $\mathrm{m}$ above the sea level) and it is composed by primary and secondary fish such as $P$. salvatoris (Posa), P. butleri (Pobu), Amatitlania nigrofasciata (Amni), Astyanax aeneus (Asae), P. marcellinoi (Poma), Synbranchus marmoratus (Syma), Rhamdia guatemalensis (Raghu), R. laticauda (Rhla) and Parachromis motaguensis (Pamo). The ANOSIM shows significant differences in species composition between the two groups $\left(\mathrm{R}^{2}=0.21\right.$, $\mathrm{p}=0.02$ ); however, the value obtained from $\mathrm{R}$ is relatively low, indicating that the two groups are separated, but with a higher degree of overlapping between them. 


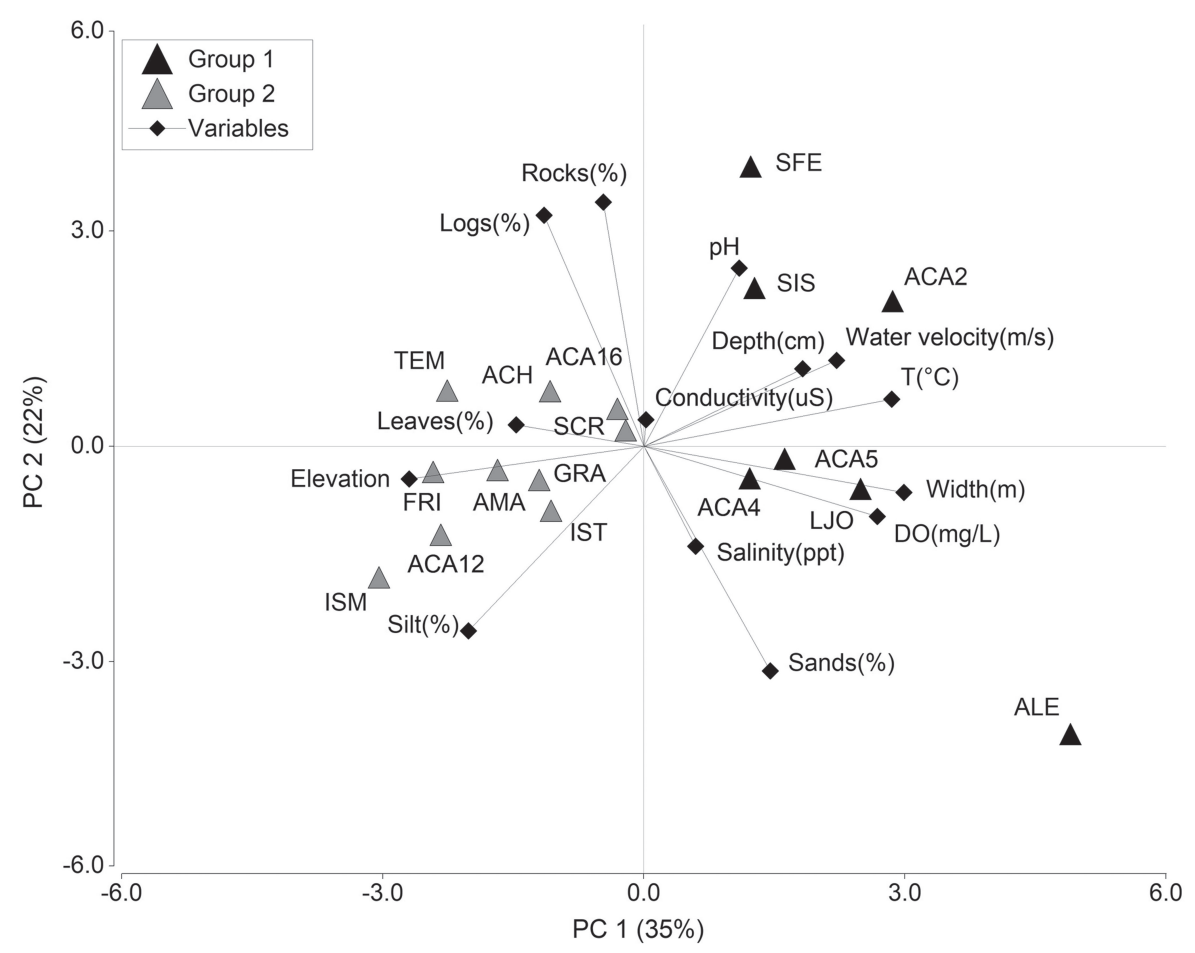

Fig. 3. Principal Component Analysis (PCA) of four physicochemical variables of the water, eight variables of habitat structure and 17 sampling sites. Localities separated by the two groups identified by CCA in the Río Acahuapa basin, San Vicente, El Salvador, 2011-2012.

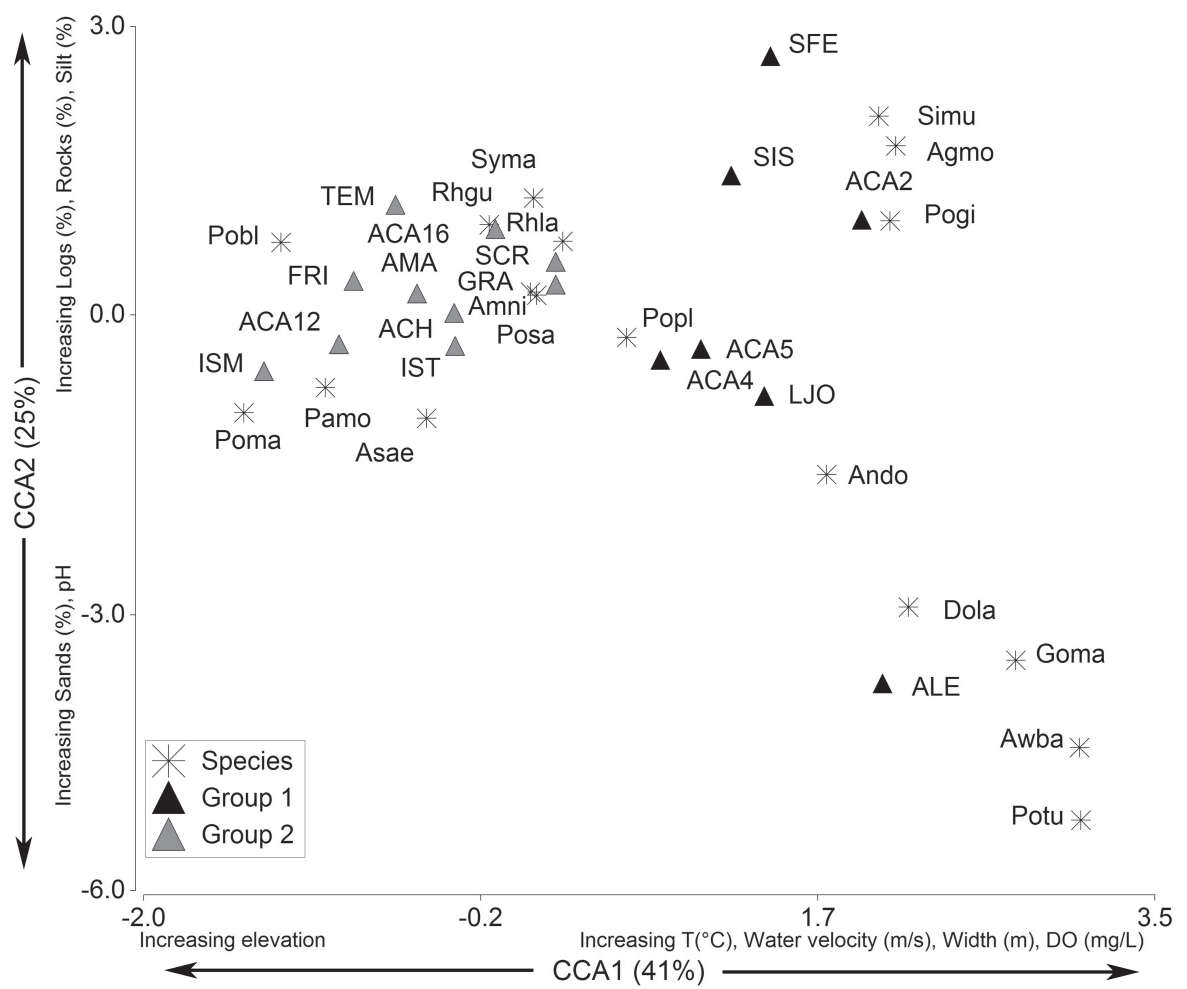

Fig. 4. Canonical Correspondence Analysis (CCA), showing 17 sites, 18 species and environmental variables of PC1 and PC2. Environmental variables used in axes had correlation coefficients $\geq 0.60$ and statistical significance ( $>0.05$ ). Two groups identified by species composition in the Río Acahuapa basin. Code of species: S. multipunctatus (Simu), A. monticola (Agmo), P. gillii (Pogi), P. pleurospilus (Popl), A. dowei (Ando), D. latifrons (Dola), G. maculatus (Goma), A. banana (Awba), P. turrubarensis (Potu), P. salvatoris (Posa), P. butleri (Pobu), A. nigrofasciata (Amni), A. aeneus (Asae), P. marcellinoi (Poma), S. marmoratus (Syma), R. guatemalensis (Raghu), R. laticauda (Rhla), P. motaguensis (Pamo). 


\section{Discussion}

Lack of studies of freshwater fishes in some countries of Central America has created gaps in information that limit the scope of studies in the region (Miller, 1966; Albert, Miller, 1995; Matamoros et al., 2012). But, recent initiatives have tried to address this problem completing and reconstructing the information of freshwater fish in Central America (e.g., Matamoros et al., 2012; 2014). In El Salvador, this research represents the first ecological assessment of freshwater fishes and contributes to support future studies at local and regional scales. The Río Acahuapa has an important number of freshwater fish species. In fact, the 33\% of the species recorded for El Salvador are reported in this basin. According to the most recent publication listing the freshwater species of El Salvador (McMahan et al., 2013), some of the records of this study become the first record for the Río Lempa basin, such as Cathorops steindachneri, A. monticola, Mugil curema, P. butleri, Bairdiella armata, D. latifrons, Eleotris picta, A. banana, S. multipunctatum and Cyclopsetta panamensis, and in the case of Trinectes fonsecensis this is the first mention in freshwater ecosystems in El Salvador. We also recorded Oreochromis niloticus "tilapia" and the P. managuensis "guapote tigre", two exotic species, whose occurrence can be linked to aquaculture practices in Apastepeque lake, that is located within the basin of the Río Acahuapa.

The largest contribution of the abundance and dominance of species recorded in this study corresponds to the families Characidae, Cichlidae and Poeciliidae. The same pattern has been observed in different studies from rivers and streams in the Central American region and some areas of Mexico, which report species corresponding to these families as the most dominant and widely distributed (Bussing, López, 1977; Angermeier, Karr, 1983; Esselman et al., 2006; Espinoza, 2007a; Espinoza, 2007b; Rojas, Rodríguez, 2007; López-López et al., 2009; Trujillo-Jiménez et al., 2010; Matamoros et al., 2012; Pease et al., 2012). Although, it is important to highlight that diadromous and marineestuarine species constitute a significant proportion of the species richness in this study. Despite that a recent research on water quality in the basin suggests that its quality ranges from regular to poor (Hernández et al., 2010), an important number of fish species inhabit the basin. In fact, the current conditions favor the migration and colonization of species of fish of marine origin. An example of this was the collection of a significant number of individuals from A. monticola (222 individuals), a diadromous fish of great value for local subsistence fishery, considered by some authors as an indicator of well-oxygenated waters and low or moderate disturbance (Cruz, 1987; Ribeiro, Villalobos, 2010). Therefore, the basin contributes to the diet of the local people and represents an important habitat for the local ichthyofauna. Consequently, studying distribution patterns in the watershed is relevant for biogeography, management and conservation of these species.
Changes in species richness in the Río Acahuapa indicate higher number of species in the lower areas of the basin, while number of species decreases as the elevation increases. These results resemble other studies in the Central American region where an inverse relationship between the species richness and the increase elevation has been identified (Lyons, Schneider, 1990; Espinoza, 2007a; Lorion et al., 2011). These changes of species composition along the altitudinal gradient of the river may respond to a gradient of environmental factors or changes in the dynamics of the habitat structure along the river. Although our environmental variables may be similar to other studies in small streams or tropical rivers (Pouilly et $a l ., 2006)$, our data show a difference with respect to river velocity, whose values are high in the intermediate and low areas of the basin, while low areas of rivers usually tend have calm waters. This can be explained because the Río Acahuapa has many tributaries in the intermediate and low areas (Hernández et al., 2010), which allows these unusual characteristics. For example, the areas of middle and low elevation were associated to the areas of riffles with greater water velocity, high concentrations of dissolved oxygen, moderate temperature, greater depth, and river width. This conditions favored some fishes, for example A. monticola and $S$. multipunctatum, as they can be swimming against current and tolerate high water velocity through physiological adaptations (Bussing, López, 1977; Phillip, 1993; Bussing, 2002; Miller et al., 2009). While in the basin upper reaches, the values of the water velocity and depth of the river are significantly reduced, presenting water with low temperatures, lower dissolved oxygen concentration, and greater substrate of logs and rocks. These conditions favored the presence of fish such as some cichlids, small poeciliids, characids and catfish, conditions where these species are usually very abundant (Bussing, López, 1977). Therefore, our results suggest that the geomorphologic characteristics of the basin driven by changes in elevation and changes in the flow of the rivers condition the habitat structure and the physicochemical factors of the water. Likewise, the change of environmental characteristics between backwaters zones and rapids zones can explain part of the composition and distribution of the fish species in the watershed, since these conditions contributed to the differentiation of two fish associations in the case of the Río Acahuapa.

The basin of the Río Acahuapa has no influence of brackish water, even though, the short distance between the mouth of the Río Acahuapa and the sea $(45 \mathrm{~km})$ favors the presence of many fish species of marine origin mainly in the lower areas of the basin. This relation between the distance of river and the sea has been observed in different studies, and some authors argue that the distance from the river to the sea is a factor that can explain the composition and distribution of fish communities in a river, because it allows the addition and flow of species by the colonization of marine origin fishes (Lyons, Schneider, 
1990; Lyons, Mercado-Silva, 1999; Esselman et al., 2006; Rojas M., Rodríguez S., 2007; Mercado-Silva et al., 2012). Therefore, the combined effect of distance from river to the sea and the elevation appear to be very important explaining species richness patterns of the Río Acahuapa. Likewise, the elevation also showed a relationship with water physicochemical variables and the habitat structure that allowed to observe changes from the headwater of the river until the mouth of the river.

This research shows a great sampling effort during almost a year of surveys, nonetheless, low abundances were recorded for some species in the different sampling events, mainly for marine-estuarine species. Due to lack of studies in freshwater ecosystems in El Salvador, it is difficult to compare our results at local scales. However, our results suggest that for many species of marine derivation, the low basin is an important site that favors its occurrence mainly at the beginning of the rains. This pattern has been observed in other studies in the region, where the rainy season between May and June increases the presence of marine-estuarine fish (Rojas, Rodríguez, 2007). Probably the presence of marine-estuarine species is favored by an increment in river flow during the rainy season and related to feeding excursions or shelter (Espinosa-Pérez et al., 2011). However, these hypotheses should be tested in future studies in the basin. Diadromous species, were present all year round, mainly in areas of low elevation (19-352 m). According to studies in the Central American region, diadromous species can be an important component within species richness in freshwater ecosystems (Bussing, López, 1977; Esselman et al., 2006; Rojas, Rodríguez, 2007; Lorion et al., 2011) and tend to be more abundant and diverse in high areas of the rivers (Lorion et al., 2011). Possibly the habitat structure and physicochemical factors of water in the río Acahuapa, basin did not favor their presence and development in high areas.

The records of temporal and seasonal distribution for this area are relevant and can be useful in future research that determines the temporal and seasonal patterns of these species with greater scientific evidence. Also, we recognize the importance of incorporating other factors that can explain the movement of species in rivers, mainly of these fish groups that depend on connected habitats between marine systems and freshwater ones. For example, some biotic factors may explain the flow and spatial distribution of some species along the basin, such as migrations along the fluvial system for breeding and mating or search for shelter (Schlosser, 1991; McDowall, 1992; Matthews, 1998; Lucas, Baras, 2001; McDowall, 2007). Also, trophic aspects may also explain associations of fish and can be related to environmental aspects in rivers (Pouilly et al., 2006). Therefore, it is important to consider these and other additional factors to complete information on the ecological dynamics in the Río Acahuapa basin.
Our findings describe some of the components that can influence the composition and distribution of the freshwater fish of the Río Acahuapa. Mainly, we evidenced a strong relationship between patterns of species richness and elevation. Also, we identified two different assemblages along the altitudinal gradient of the basin. Likewise, we evidenced that much of species richness come from primary and secondary species; however, marine-estuarine species contribute greatly to species richness in this basin. We hope that our result will be the starting point for future research. Also, we hope this information will be of paramount interest to decision makers on the management and conservation of biodiversity.

\section{Acknowledgments}

We express our gratitude to the Ministerio de Medio Ambiente y Recursos Naturales de El Salvador for issuing the collection permissions for this study and special thanks to Arami Martínez for the field assistance and support. We are grateful to the Universidad de El Salvador, Departamento de Biología for their support. We also express our gratitude to Arturo Angulo, Michelle Recinos, Wendy Henríquez, Alexis Flores, Maythé Morán, Marcela Puro and Wilson Martínez for their cooperation in this work.

\section{References}

Acolas ML, Lambert P. Life histories of anadromous fishes. In: Morais P, Daverat F, editors. An introduction to fish migration. Florida, USA: CRC Press; 2016. p.55-78.

Albert JS, Miller RR. Gymnotus maculosus, a new species of electric fish (Chordata: Teleostei: Gymnotoidei) from Middle America, with a key to species of Gymnotus. Proc Biol Soc Wash. 1995; 108(4):662-78.

Álvarez FS, Recinos HM, Henríquez WY. First record of Heterandria anzuetoi (Cyprinodontiformes: Poeciliidae) in El Salvador. Rev Mex Biodivers. 2013; 84(4):1335-37.

Angermeier PL, Karr JR. Fish communities along environmental gradients in a system of tropical streams. Env Biol Fish. 1983; 9(2):117-35.

Angermeier PL, Smogor RA. Estimating number of species and relative abundances in stream-fish communities: effects of sampling effort and discontinuous spatial distributions. Can J Fish Aquat Sci. 1995; 52(5):936-49.

Angulo A, Garita-Alvarado CA, Bussing WA, López MI. Annotated checklist of the freshwater fishes of continental and insular Costa Rica: additions and nomenclatural revisions. Check List. 2013; 9(5):987-1019.

Bray JR, Curtis JT. An ordination of the upland forest communities of southern Wisconsin. Ecol Monogr. 1957; 27(4):325-49.

Bussing WA. Peces de las aguas continentales de Costa Rica. San José, Costa Rica: Universidad de Costa Rica; 2002.

Bussing WA, López S. MI. Distribución y aspectos ecológicos de los peces de las cuencas hidrográficas de Arenal, Bebedero y Tempisque, Costa Rica. Rev Biol Trop. 1977; 25(1):13-37. 
Cao Y, Larsen D, Thorne RSJ. Rare species in multivariate analysis for bioassessment: some considerations. J N Am Benthol Soc. 2001; 20(1):144-53.

Castro-Aguirre JL, Pérez E, Soto HS. Ictiofauna estuarinolagunar y vicaria de México. México: Noriega-Limusa; 1999.

Clarke KR. Non-parametric multivariate analyses of changes in community structure. Aust J Ecol. 1993; 18(1):117-43.

Cruz GA. Reproductive biology and feeding habits of cuyamel, Joturus pichardi and tepemechín, Agonostomus monticola (Pisces; Mugilidae) from Rio Plátano, Mosquitia, Honduras. Bull Mar Sci. 1987; 40(1):63-72.

Di Rienzo J, Casanoves F, Balzarini M, Gonzalez L, Tablada M, Robledo C. InfoStat versión 2011 [Computer softwareinternet]. Argentina: Grupo InfoStat, FCA, Universidad Nacional de Córdoba; 2011. Available from http://www. infostat.com.ar

Di Rienzo JA, Casanoves F, Pla L, Vílchez S, Di Rienzo MJ. QecoQuantitative ecology software: A collaborative approach. Rev Lat Cons. 2010; 1(1):73-75.

Espinosa-Pérez HJLC-A, González-Acosta AF. Los peces costeros. In: Espino GL, Pulido SH, editors. Ambiente, biología, sociedad, manejo y legislación de sistemas costeros mexicanos. México: Plaza y Valdes Editores; 2011. p.181-207.

Espinoza MM. Composición y estructura de las comunidades de peces del río La Cañaza, Pacífico Sur de Costa Rica. Brenesia. 2007a; 67:35-43.

Espinoza MM. Sondeo ecológico rápido de las comunidades de peces tropicales en un área de explotación minera en Costa Rica. Rev Biol Trop. 2007b; 56(4):1971-90.

Esselman PC, Allan JD. Relative influences of catchment- and reach-scale abiotic factors on freshwater fish communities in rivers of northeastern Mesoamerica. Ecol Freshw Fish. 2010; 19(3):439-54.

Esselman PC, Freeman MC, Pringle CM. Fish-assemblage variation between geologically defined regions and across a longitudinal gradient in the Monkey River Basin, Belize. J N Am Benthol Soc. 2006; 25(1):142-56.

Greenfield DW, Thomerson JE. Fishes of the continental waters of Belize. Florida: University Press of Florida; 1997.

Hernández Martínez M, Serrano Cervantes L, Sermeño CJ, Paniagua M, Pérez D, Springer M, Urias Monterrosa AJ. Atlas geográfico de los insectos acuáticos indicadores de calidad ambiental del agua de los ríos de El Salvador. In: Springer M, Sermeño CJ, editors. Formulación de una guía metodológica estandarizada para determinar la calidad ambiental de las aguas de los ríos de El Salvador, utilizando insectos acuáticos. El Salvador: Proyecto Universidad de El Salvador (UES)-Organizacion de los Estados Americanos (OEA); 2010. p.1-104.

Hildebrand SF. Fishes of the Republic of El Salvador, Central America. Bulletin of the Bureau of Fisheries. 1925; 41:237-87.

Hughes RM, Kaufmann PR, Herlihy AT, Intelmann SS, Corbett $\mathrm{SC}$, Arbogast MC, Hjort RC. Electrofishing distance needed to estimate fish species richness in raftable Oregon rivers. N Am J Fish Manage. 2002; 22(4):1229-40.
Jackson DA, Peres Neto PR, Olden JD. What controls who is where in freshwater fish communities: the roles of biotic, abiotic, and spatial factors. Can J Fish Aquat Sci. 2001; 58(1):157-70.

Junqueira NT, Macedo DR, Souza RCR, Hughes RM, Callisto M, Pompeu PS. Influence of environmental variables on stream fish fauna at multiple spatial scales. Neotrop Ichthyol. 2016; 14(3):e150116.

Kihn-Pineda P, Cano E, Morales A. Peces de las aguas interiores de Guatemala. In: Cano E, editor. Biodiversidad de Guatemala. Guatemala: Universidad del Valle de Guatemala; 2006. p.457-486.

López-López E, Sedeño-Díaz JE, Romero FL, Trujillo-Jiménez P. Spatial and seasonal distribution patterns of fish assemblages in the Río Champotón, southeastern Mexico. Rev Fish Biol Fisheries. 2009; 19(2):127-42.

Lorion CM, Kennedy BP, Braatne JH. Altitudinal gradients in stream fish diversity and the prevalence of diadromy in the Sixaola River basin, Costa Rica. Environ Biol Fish. 2011; 91(4):487-99.

Lowe-McConnell RH. Ecological studies in tropical fish communities. New York: Cambridge University Press; 1987.

Lucas MC, Baras E. Migration of freshwater fishes. London: Blackwell Science Ltd; 2001.

Lyons J. The length of stream to sample with a towed electrofishing unit when fish species richness is estimated. N Am J Fish Manage. 1992; 12(1):198-203.

Lyons J. Distribution of Sicydium Valenciennes 1837 (Pisces: Gobiidae) in Mexico and Central America. Hidrobiológica. $2005 ; 15(2): 239-43$

Lyons J, Mercado-Silva N. Patrones taxonómicos y ecológicos entre comunidades de peces en ríos y arroyos en el oeste de Jalisco, México. Anales del Instituto de Biología serie Zoología. 1999; 70(2):169-90.

Lyons J, Schneider DW. Factors influencing fish distribution and community structure in a small coastal river in southwestern Costa Rica. Hydrobiologia. 1990; 203(1-2):1-14.

Magurran AE, Henderson PA. Explaining the excess of rare species in natural species abundance distributions. Nature. 2003; 422(6933):714-16.

Matamoros WA, Kreiser BR, Schaefer JF. A delineation of Nuclear Middle America biogeographical provinces based on river basin faunistic similarities. Rev Fish Biol Fisheries. 2012; 22(1):351-65.

Matamoros WA, McMahan CD, Chakrabarty P, Albert JS, Schaefer JF. Derivation of the freshwater fish fauna of Central America revisited: Myers's hypothesis in the twenty-first century. Cladistics. 2014; 31(2):177-88.

Matamoros WA, Schaefer JF, Kreiser BR. Annotated checklist of the freshwater fishes of continental and insular Honduras. Zootaxa. 2009; 2307:1-38.

Matthews WJ. Patterns in freshwater fish ecology. New York: Chapman \& Hall; 1998.

McDowall RM. Particular problems for the conservation of diadromous fish. Aquat Conserv Mar Freshw Ecosyst. 1992; 2(4):351-55. 
McDowall RM. On amphidromy, a distinct form of diadromy in aquatic organisms. Fish Fish. 2007; 8(1):1-13.

McDowall RM. Diadromy, history and ecology: a question of scale. Hydrobiologia. 2008; 602(1):5-14.

McMahan CD, Matamoros WA, Álvarez FS, Henríquez WY, Recinos HM, Chakrabarty P, Barraza E, Herrera N. Checklist of the inland fishes of El Salvador. Zootaxa. 2013; 3608(6):440-56.

Mercado-Silva N, Lyons J, Díaz-Pardo E, Navarrete S, GutiérrezHernández A. Environmental factors associated with fish assemblage patterns in a high gradient river of the Gulf of Mexico slope. Rev Mex Biodivers. 2012; 83(1):117-28.

Miller RR. Geographical distribution of Central American freshwater fishes. Copeia. 1966(4):773-802.

Miller RR, Minckley W, Norris SM. Peces dulceacuícolas de México. México: Comisión Nacional para el Conocimiento y Uso de la Biodiversidad; 2009.

Myers GS. Salt-tolerance of fresh-water fish groups in relation to zoogeographical problems. Bijdragen tot de Dierkunde. 1949a; 28:315-22.

Myers GS. Usage of anadromous, catadromous and allied terms for migratory fishes. Copeia. 1949b; 1949(2):89-97.

Pease AA, González Díaz AA, Rodiles Hernández R, Winemiller KO. Functional diversity and trait-environment relationships of stream fish assemblages in a large tropical catchment. Freshwater Biol. 2012; 57(5):1060-75.

Phillip DAT. Reproduction and feeding of the mountain mullet, Agonostomus monticola, in Trinidad, West Indies. Environ Biol Fishes. 1993; 37(1):47-55.

Pouilly M, Barrera S, Rosales C. Changes of taxonomic and trophic structure of fish assemblages along an environmental gradient in the Upper Beni watershed (Bolivia). J Fish Biol. 2006; 68(1):137-56.

Rahel FJ, Hubert WA. Fish assemblages and habitat gradients in a Rocky Mountain-Great Plains stream: biotic zonation and additive patterns of community change. Trans Am Fish Soc. $1991 ; 120(3): 319-32$.
Ribeiro TC, Umaña Villalobos G. Distribution of Agonostomus monticola and Brycon behreae in the Río Grande de Térraba, Costa Rica and relations with water flow. Neotrop Ichthyol. 2010; 8(4):841-49.

Rojas M. JR, Rodríguez O. Diversidad y abundancia ictiofaunística del río Grande de Térraba, sur de Costa Rica. Rev Biol Trop. 2007; 56(3):1429-47.

Schlosser IJ. Stream fish ecology: a landscape perspective. BioScience. 1991; 41(10):704-12.

Smith WE, Kwak TJ. A capture-recapture model of amphidromous fish dispersal. J Fish Biol. 2014a; 84(4):897-912.

Smith WE, Kwak TJ. Otolith microchemistry of tropical diadromous fishes: spatial and migratory dynamics. J Fish Biol. 2014b; 84(4):913-28.

Trujillo-Jiménez P, López-López E, Díaz Pardo E, Camargo JA. Patterns in the distribution of fish assemblages in Río Amacuzac, Mexico: influence of abiotic factors and biotic factors. Rev Fish Biol Fisheries. 2010; 2(4):457-69.

Vannote RL, Minshall GW, Cummins KW, Sedell JR, Cushing CE. The river continuum concept. Can J Fish Aquat Sci. 1980; 37(1):130-37.

Watkins CJ, Quist MC, Shepard BB, Ireland SC. Electrofishing effort requirements for estimating species richness in the Kootenai River, Idaho. Northwest Sci. 2016; 90(3):315-27.

Winemiller KO, Agostinho AA, Caramaschi EP. Fish ecology in tropical streams. In: Dudgeon D, editor. Tropical stream ecology. London: Academic Press; 2008. p.107-46.

Wootton RJ. Fish ecology. New York: Chapman and Hall; 1992.

Wootton JT, Oemke MP. Latitudinal differences in fish community trophic structure, and the role of fish herbivory in a Costa Rican stream. Env Biol Fish. 1992; 35(3):311-19.

Submitted June 24, 2016 Accepted September 04, 2017 by Lilian Casatti 